\title{
Study of the quality of life in amputee soccer players
}

\author{
José Ricardo Auricchio(1), Nathalia Bernardes ${ }^{(2)}$, Marlene Aparecida Moreno(3)
}

\begin{abstract}
Introduction: Although a number of aspects related to amputation have a negative impact on quality of life, sports can prevent disease and promote health in this population just as it can among the nondisabled. Objective: The aim of this study was to evaluate the quality of life in amputee soccer players $(n=25)$. Method: We compared scores on the World Health Organization Quality-of-Life Scale (WHOQOL-BREF). Results: observing that the physical (PHY: 71 \pm 16$)$, psychological (PSY: 76 \pm 18 ) and social domains (SOC: $72 \pm 22$ ) showed higher values $(p<0.05)$ than the environment domain (ENV: $55 \pm 17)$. There was a positive correlation between PHY and PSY ( $r: 0.8)$, PHY and SOC ( $r: 0.7)$ and PHY and ENV ( $r: 0.7)$. Moreover, PHY showed a positive correlation with SOC (r: 0.9) and ENV (r: 0.8). In addition, the adapted sport improved the overall quality of life index (GQOLI= 71.50). Conclusion: These results show that amputee soccer improves the quality of life of its players.
\end{abstract}

Keywords: Soccer; Amputation; Quality of life; Rehabilitation Exercise.

\section{INTRODUCTION}

Amputation causes serious aesthetic, functional, emotional, social, economic and psychological alterations to a person's life. ${ }^{(1)}$ Besides compromised self-esteem, mobility and work and leisure activities, ${ }^{(2)}$ many lower-limb amputees have difficulty with balance, coordination and walking, all aspects related to fear of falling. Thus, it is believed that all these factors have negative repercussions on the quality of life of this population. ${ }^{(3)}$

Functional incapacity due to lower-limb amputation interferes with autonomy and independence, ${ }^{(4)}$ and rehabilitation programs for this group aim to restore autonomy in locomotion and activities of daily living, as well as to help with cognitive, emotional and social aspects. ${ }^{(5,6)}$ Thus, one objective for amputee rehabilitation is to improve functional capacity, which, consequently, impacts quality of life.

It is reported that physical well-being is directly related to a lack of disease or compromise to locomotive capacity and, moreover, since good physical health is considered a strong indicator of psychological well-being, ${ }^{(7)}$ these are important factors in amputee quality of life. For this reason, new rehabilitation alternatives should be proposed in order to maintain good health conditions for the disabled, especially exercise programs. Among such proposals, recreation and sports stand out for helping prevent disease and boosting health, as well as for contributing to functional independence, ${ }^{(8)}$ and amputee soccer is one such option for this population.
This sport was adapted for the disabled in a prevention and rehabilitation context after the Second World War and has become an important rehabilitation tool for this population due to its motor, psychological and social benefits, besides its competitive and leisure aspects, which are considered accelerators of the rehabilitation process. ${ }^{(9)}$ Amputee soccer, although adapted relatively recently, has demonstrated benefits for players. Yanci and Banu observed that the sport affects the quality of life of amputees, ${ }^{(10)}$ a factor necessary for rehabilitation's goals of greater self-esteem and independence for the disabled.

Thus, the aim of the present study was to evaluate the quality of life of amputee soccer players on a team from greater São Paulo.

\section{MATERIALS AND METHOD}

The study followed the national and international ethical standards. This cross-sectional study was approved by the University Methodist of Piracicaba Ethics Committee (09/2015).

A total of 25 male amputee soccer players were evaluated, all of whom had been playing for at least three months, were between 18 and 45 years old, and were defenders or goalkeepers.

The WHOQOL-BREF questionnaire, which is an abbreviation the WHOQOL-100, was used to evaluate quality of life. 
This instrument, developed and validated by the World Health Organization, consists of the 26 best-performing psychometric questions from the WHOQOL-100, which are divided into four domains: physical, psychological, social and environmental, as well as two questions categorized under a general domain. Domain 1, Physical health, refers to questions about the individual's pain perception, the amount of pain medication used, the ability to perform activities of daily living, work capacity, and sleep. Domain 2, Psychological health, involves questions about feelings, satisfaction and personal acceptance, concentration and personal beliefs. Domain 3, Social relationships, includes questions about relationships with friends and parents, as well as sexual activity. Domain 4, Environment, deals with the home environment, physical safety and security, financial resources, learning opportunities, leisure, means of transport and health care. The two general questions are scored together independently from the other domains and are called the General Quality of Life Index (GQOLI). ${ }^{(11)}$

Instructions on filling out the form were provided to the interviewers; however, all participants answered the questions by themselves based on their experience in the last two weeks.

\section{STATISTICAL ANALYSIS}

The collected data were input into Microsoft Excel ${ }^{\circledR}$ spreadsheets and scored according to Pedroso et al. ${ }^{(12)}$ GraphPad InStat software was used for the statistical analysis. The Shapiro-Wilk test was used to verify normal distribution, followed by one-way ANOVA and a post-hoc Tukey test to analyze significance. The relationship between domains and quality of life was evaluated using the Pearson correlation coefficient. Values above $p<0.05$ were considered statistically significant. The data are presented as means and standard deviation.

\section{RESULTS}

Table 1 presents the sample's characteristics regarding age, body mass, height, BMI, length of disability and time involved in the sport. The mean subject age was 30 years with a BMI considered eutrophic. ${ }^{(13)}$ The length of disability and time involved in the sport were 13 and 4 years, respectively.

Table 2 shows the differences between quality-of-life domain results: values for the environment domain were lower than those of the physical, psychological and social domains.

Table 3 shows the results of the correlation analysis between quality-of-life domains: there was a significant positive correlation between all domains, and the determination coefficient $\left(r^{2}\right)$ values were above 0.50 for all variables.

Figure 1 presents the results by each domain facet (0-100 points), with scores above 70 considered a good quality-of-life index. ${ }^{(14)}$ The facet with the highest quality-of-life index among the athletes was that of body image and appearance, which belongs to the physcological domain.
On the other hand, the facet with the lowest quality-of-life was transportation, which belongs to the environment domain. The athletes presented a good general quality-of-life index (GQOLI = 71.50).

\section{DISCUSSION}

The main findings of this study show that, with the exception of the environment domain, amputee football players present satisfactory responses regarding quality of life. Quality of life is scored positively, i.e., the greater the score, the better the quality of life in the studied population. ${ }^{(11)}$ Indices above 70 points are considered satisfactory quality of life, while those below 70 are considered unsatisfactory. ${ }^{(14)}$

One recent study of a nondisabled population showed unfavorable psychological domain results but favorable environmental domain results. ${ }^{(15)}$ On the other hand, in a study with a different disabled population, ${ }^{(16)}$ the environmental results were the worst, independently of location. We found similar data in our study regarding an unsatisfactory environmental domain, especially the transportation facet, whose mean was a mere 43 points.

Table 1. Characterization of the sample $(n=25)$

\begin{tabular}{lc}
\hline & $\mathrm{M} \pm \mathrm{SD}$ \\
\hline Age (years) & $29.13 \pm 7.19$ \\
Body mass $(\mathrm{kg})$ & $68.24 \pm 13.81$ \\
Height $(\mathrm{cm})$ & $172 \pm 7$ \\
BMI $\left(\mathrm{kg} / \mathrm{m}^{2}\right)$ & $23.37 \pm 3.14$ \\
Time disabled (months) & $126.83 \pm 117.27$ \\
Time of soccer participation (months) & $54.5 \pm 64.06$
\end{tabular}

$\mathrm{BMI}=$ body mass index; $\mathrm{M}=$ mean; $\mathrm{SD}=$ standard deviation

Table 2. Comparison of WHOQOL-BREF quality-of-life domain results.

\begin{tabular}{|c|c|c|c|}
\hline PHY & PSY & SOC & ENV \\
\hline $70.98 \pm 16.16$ & $76.12 \pm 18.12$ & $71.81 \pm 21.93$ & $55.34 \pm 16.73 *+$ \\
\hline \multicolumn{4}{|c|}{$\begin{array}{l}\text { Data presented as mean } \pm \text { standard deviation. }{ }^{*} p<0.05 \text { : ENV } \times \text { PHY; ENV } \times \text { SOC; } \uparrow p<0.001 \\
\text { ENV } x \text { PHY. PHY: physical domain; PSY: psychological domain; SOC: social doamin } \\
\text { ENV: environmental domain. }\end{array}$} \\
\hline Domains & $\mathbf{r}$ & $r^{2}$ & $p$-value \\
\hline PHY vs. PSY & 0.80 & 0.64 & 0.0001 \\
\hline PHY vs. SOC & 0.73 & 0.53 & 0.0001 \\
\hline PHY vs. ENV & 0.73 & 0.54 & 0.0001 \\
\hline PSY vs. SOC & 0.88 & 0.77 & 0.0001 \\
\hline PSY vs. ENV & 0.78 & 0.62 & 0.0001 \\
\hline SOC vs. ENV & 0.86 & 0.75 & 0.0001 \\
\hline
\end{tabular}

PHY: physical domain; PSY: psychological domain; SOC: social doamin; ENV: environmental domain. 

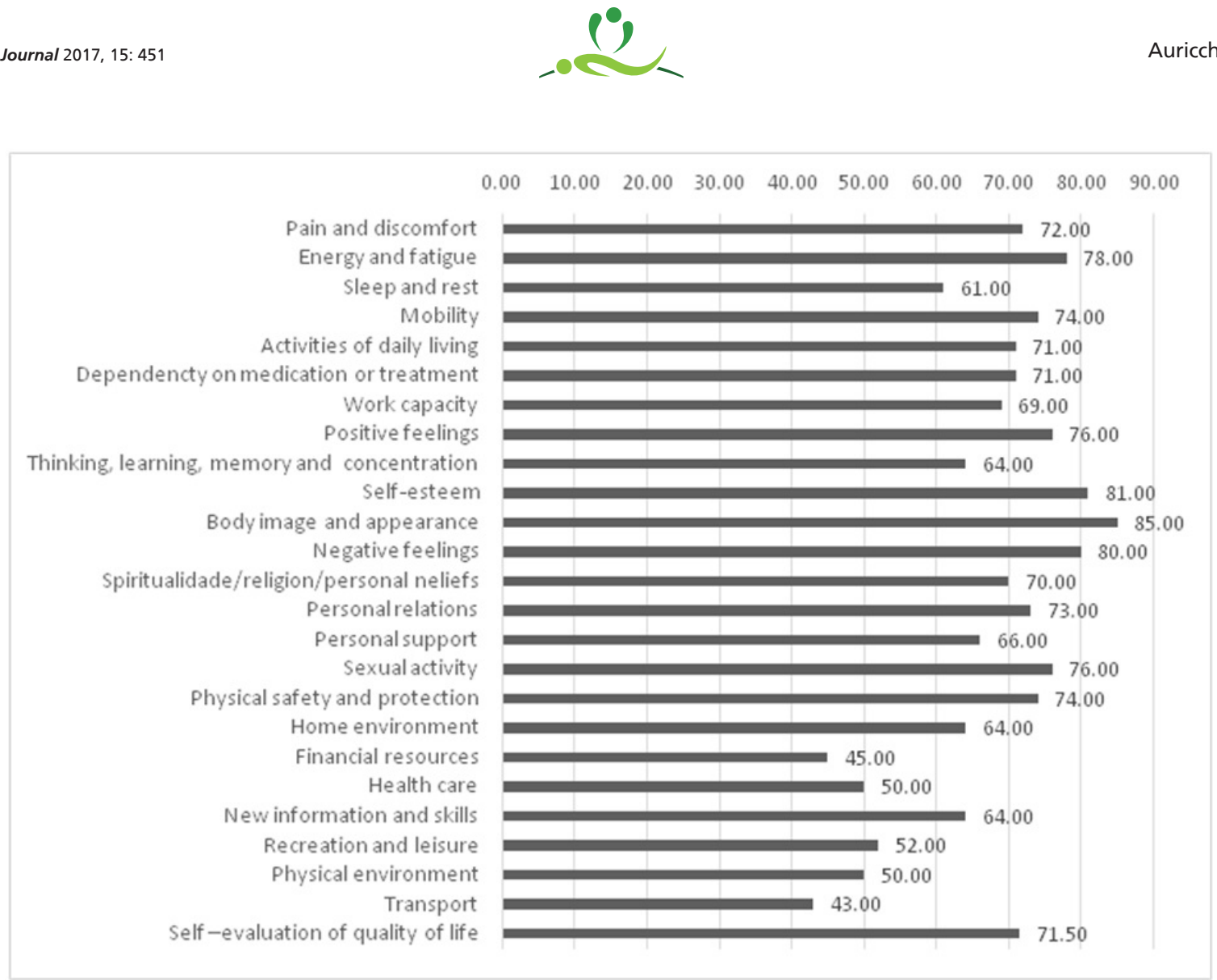

Figure 1. Results for specific facets of the WHOQOL-BREF quality-of-life domains.

When quality-of-life indices were compared between disabled, sedentary and physically active populations, the best results were found among the physically active group, especially in the psychological domain: the physically active group had a mean score of 81.94 vs. 54.58 for the sedentary group. This result resonates with the findings of the present study, in which the psychological domain obtained the highest index $(76.12 \pm 18.12)$ among all four domains. ${ }^{(17)}$

Physical activity, especially team sports, is important for the emotional and social well-being of the disabled, since such activity can help improve social skills. For this reason the social problems and integration difficulties of the disabled, as well as their causes and the obstacles they represent, have been the focus of research. ${ }^{(18,19)}$

Sports can improve the quality of life of the disabled, especially the social dimension. It is worth pointing out, however, that even in the recent surge in research on socialization problems among the disabled, little attention has been devoted to the influence of physical activity/sports and its psychosocial impact. ${ }^{(19)}$

One study that used the SF-36 questionnaire to compare the effects of balance, strength and quality of life among unilateral amputees who did or did not play soccer found statistically significant differences in physical function, pain and emotional aspects between the groups. ${ }^{(2)}$ The differences were not significant regarding general health, vitality and mental health, which indicates that the greatest improvements were to physiological and physical aspects, similarly to what was found in the present study.

The improved emotional functioning observed in the above-mentioned study was attributed to the use of sports as an auxiliary form of therapy and rehabilitation, ${ }^{(20)}$ strengthening the subjects' capacity to deal with psychological problems, given that symptoms of depression can occur post-amputation. ${ }^{(21,22)}$

In another study, quality of life and life satisfaction were evaluated among disabled individuals who were either physically active or sedentary. ${ }^{(16)}$ It was found that those involved in sports had a better quality of life and a higher index of life satisfaction than those who were not. Our results also showed GQOLI values consistent with satisfactory quality of life, which suggests that soccer seems to positively influence the quality of life of this population.

Other studies with disabled individuals ${ }^{(19,23,24)}$ have found that physical activity promotes a number of health-related benefits, including metabolic, musculoskeletal and 
cardiorespiratory aspects. Thus, there is improvement in activities of daily living, which contributes to a better perception of quality of life, principally in the physical aspect. With respect to the physical domain in the present investigation, the results were over 70 points, which agrees with the findings of the above-mentioned authors for physically-active disabled individuals.

Regarding the correlation analyses, a stronger correlation was observed between the psychological and social domains, followed by social and environmental domains. The weakest correlation was between the physical and social domains, followed by the physical and environmental domains. These results demonstrate that the psychological domain positively influences an individual's social relations. Moreover, the social domain positively influences environmental questions. The physical domain, in turn, positively influences social and environmental aspects, in that it involves the individual's locomotion and safety, which are important aspects in activities of daily living.

\section{CONCLUSIONS}

According to the findings of this study, in can be concluded that the quality of life of amputee soccer players, with the exception of the environment domain, present satisfactory indices, suggesting that participation in this sport makes them physically active and thus brings them all the benefits that regular physical exercise brings to its practitioners.

\section{ACKNOWLEDGEMENTS}

CAPES and SMEL Mogi Futebol de Amputados.

\section{AUTHORS' CONTRIBUTIONS}

JRA, contributed to acquisition of data, analysis and interpretation of data, statistical analysis and draft the manuscript; NB contributed to analysis of data and draft the manuscript; MAM contributed to design of the work, analysis and interpretation of data and statistical analysis.

\section{CONFLICT OF INTEREST}

Nothing to declare

\section{AUTHOR DETAILS}

${ }^{2}$ Phd - Universidade Nove de Julho (UNINOVE), São Paulo (SP), Brasil ${ }^{3}$ Phd - Universidade Metodista de Piracicaba (UNIMEP), Piracicaba (SP), Brasil

\section{REFERENCES}

1. Lima KBB, Chamlian TR, Masiero D. Dor fantasma em amputados de membro inferior como fator preditivo de aquisição de marcha com prótese. Revista Acta Fisiatrica. 13(3):157-62. 2006.

2. Bruins M, Geertzen JH, Groothoff JW, Schoppen T. Vocational reintegration after a lower limb amputation: a qualitative study. Prosthetics and orthotics international. 27(1):4-10. 2003.

3. Miller WC, Deathe AB, Speechley M, Koval J. The influence of falling, fear of failing, and balance confidence on prosthetic mobility and social activity among individuals with a lower extremity amputation. Archives of Physical Medicine and Rehabilitation. 82:1238-44. 2001.
4. Diogo MJD. A dinâmica dependência-autonomia em idosos submetidos à amputação de membros inferiores. Revista Latino Americana Enfermagem.5(1):59-64. 1997.

5. van Eijk MS, van der Linde $H$, Buijck B, Geurts A, Zuidema S, Koopmans R. Predicting prosthetic use in elderly patients after major lower limb amputation. Prosthetics and orthotics international.36(1):45-52. 2012.

6. Fortington LV, Rommers GM, Geertzen JHB, Postema K, Dijkstra PU. Mobility in elderly people with a lower limb amputation: a systematic review. Journal of the American Medical Directors Association. 13(4):31925. 2012.

7. Diogo MJD. Avaliação funcional de idosos com amputação de membros inferiores atendidos em um hospital universitário. Revista Latino Americana Enfermagem. 11(1):59-65. 2003.

8. Hansen N, Forchheimer M, Tate D, Luera G. Relationships among community reintegration, coping strategies, and life satisfaction in a sample of persons with spinal cord injury. Topics in Spinal Cord Injury Rehabilitation 4: 56-72. 1998.

9. Cardoso VD. A reabilitação de pessoas com deficiência através do desporto adaptado. Revista Brasileira Ciências do Esporte, v. 33, n. 2, p. 529-539. 2011.

10. Yanci A, Banu H. Comparison of the quality of life of footballer and nonfootballer amputees. International Journal of Academic Research. Mar. Vol. 6 Issue 2, p350-355. 2014.

11. Fleck MPA, Louzada S, Xavier M, Chachamovich E, Vieira G, Santos L, Pinzon V.. Aplicação da versão em português do instrumento abreviado de avaliação de qualidade de vida "WHO- QOL-bref". Revista Saúde Pública. 34(2):178-83. 2000.

12. Pedroso B, Pilatti LA, Gutierrez GL, Picinin CT. Cálculo dos escores e estatística descritiva do WHOQOL-bref através do Microsoft Excel. Revista Brasileira de Qualidade de Vida. v. 02, n. 01, jan./jun. p. 31-36. 2010.

13. Organização Mundial da Saúde. Divisão de saúde mental. Grupo WHOQOL. Grupo de Estudos em Qualidade de Vida. Versão em português dos instrumentos de avaliação de qualidade de vida. Porto Alegre, UFRGS, 1998

14. Vilela Junior GB, Prates Dm, Semionatto AF, Pinheiro GS. Qualidade de Vida apesar das perdas na capacidade funcional de idosos. In: OLIVEIRA, Heleise Faria Reis. (Org.). Qualidade de vida, esporte e sociedade. 1ed. Ponta Grossa: UEPG. v. 2, p. 320-324. 2006.

15. Baraldi S, Bampi LNS, Pereira MF, Guilhem DB, Mariath AB, Campos ACO. Avaliação de qualidade de vida em estudantes de nutrição. Trabalho Educação e Saúde, Rio de Janeiro, v.13 n.2, p.515-531. 2015

16. Yazicioglu K, Yavuz F, Goktep AS, Tan AK. Influence of adapted sports on quality of life and life satisfaction in sport participants and non-sport participants with physical disabilities. Disability and health Journal 5 249-253. 2012

17. Noce F, Simim MAM, Mello MT. A percepção da qualidade de vida de pessoas portadoras de deficiência física pode ser influenciada pela prática de atividade física? Revista Brasileira de Medicina do Esporte - Vol 15, N³. 2009.

18. Adomaitienè R. Neigaliųjų sociologijos pagrindai: negalių modeliai, socialinè integracija. In: ADOMAITIENÉ, Rima (Ed.), Projektas Pedagogu kvalifi kacijos kèlimas darbui su įvairias negaliasturinčiais mokiniais bendrojo lavinimo mokyklose. Metodinè medžiaga (p. 5-28). Kaunas:Lietuvos kūno kultūros akademija, 2007.

19. Mockeviciene D, Savenkoviene A. Aspects of life quality of persons with physical disabilities. Social Welfare Interdisciplinary Approach. Vol. 2 Issue 2. 2012.

20. Yazicioglu K, Taskaynatan MA, Guzelkucuk U, Tugcu I. Effect of Playing Football (Soccer) on Balance, Strength, and Quality of Life in Unilateral Below-Knee Amputees. American Journal of Physical Medicine \& Rehabilitation, v. 86, n. 10, p. 800- 805, 2007. 
21. Schoppen T, Boonstra A, Groothoff JW, De Vries J, Goeken LN, Eisma WH. Physical, mental, and social predictors of functional outcome in unilateral lower-limb amputees. Archives of Physical Medicine and Rehabilitation. 84:803-11. 2003.

22. Schubert DS, Burns, Paras W, Sioson E. Decrease of depression during stroke and amputation rehabilitation. General Hospital Psychiatry. 14:135-41. 1992.
23. Zuchetto AT, Castro RVG. As contribuições das atividades físicas para a qualidade de vida dos deficientes físicos. Knesis. (26:52-68). 2002.

24. Auricchio JR, Bernardes N, Moreno MA. Perfil metabólico e hemodinâmico dos jogadores da seleção brasileira de futebol para amputados: o esporte adaptado como prevenção de doenças cardiovasculares. Revista Sociedade Cardiologia do Estado de São Paulo - Suplemento Vol. 26 $n^{\circ} 2 b-$ Abr-Mai-Jun . 2016. 